American Journal of Environmental Sciences 7 (3): 286-294, 2011

ISSN 1553-345X

(C) 2011 Science Publications

\title{
The Impact of Air Pollution on Human Health: Focusing on the Rudnyi Altay Industrial Area
}

\author{
Vitaliy G. Salnikov and Marat A. Karatayev \\ Al-Farabi Kazakh National University, Almaty, Kazakhstan
}

\begin{abstract}
Problem statement: Air pollution in Kazakhstan is significant environmental problem. The air pollution level of cities and industrial centers remains rather high. The highest level of air pollution is registered in Ridder, Ust-Kamenogorsk, Almaty, Zyryanovsk, Aktau, Atyrau, Shymkent, Taraz, Petropavlovsk and Temirtau. The enterprises of the Rudnyi Altay, Pavlodar Oblast and enterprises of oil and gas complex in West-Kazakhstan, Atyrau and Mangistau Oblasts play the negative role in air pollution. About one third of industrial enterprises have no sanitary protective zones of standard sizes. A considerable part of the population of industrial centers live in the zone of a direct impact of harmful industrial factors emissions of polluting substances into the air, noise, vibration, electrical magnet fields and other physical factors (Dahl et al., 2001; Kaiser and Pulsipher, 2007; Farmer and Farmer, 2000). Under the conditions of the air polluter impact there is high morbidity and mortality from cardio-vascular diseases, respiratory disease, nervous system and sensory organ disturbances, gastrointestinal disease and circulatory disease. Poor air quality has been cited as a factor in these conditions (Jensena et al., 1997; Namazbaeva et al., 2010). Then we provide details a correlation between the level of disease of malignant tumors and the emissions from stationary sources in Rudnyi Altay industrial area. To reveal the quantitative relationship between the disease of malignant tumors and the change in the quantity of emissions was carried out regression analysis and model. Regression analysis and model confirms a significant direct correlation between the incidence of malignant tumors and the amount of emissions from stationary sources (correlation coefficient $R=0,6$ ). Analysis of vital statistics revealed the increased disease rate. Conclusion: Health status of the populations is negatively affected by the unfavorable environmental situation, emissions in general and technogenic hotspots. Airpollution-related health effects can be reduced through policies that curb emissions. Among measures that can be undertaken to achieve these reductions is the use technology in industry and programs to increase public awareness. However Kazakhstani society is more concerned about social problems; government does not want to disturb people, because environmental problems are far from a positive decision.
\end{abstract}

Key words: Air pollution, human health

\section{INTRODUCTION}

The condition of the population's health depends on social-economical circumstance, sanitary and epidemiological situation, preventive public health measures and the ecological conditions of the territory. One of the main ecological factors increasing the population's morbidity and influencing its physical level of development, possibility of reproduction, liability to morbidity and life duration seems to be the high level of air pollution on the atmosphere.

Between the population's health and the quality of atmosphere, they have a close connection. Dispersing harmful substance into the atmosphere creates a greater concentration of pollutions, striking on the first turn upper airways and other parts of human's organs. Inhaling polluted air into the windpipe and bronchial tubes affects alveoli, where the dirt will enter in the blood and lymph. Consequences on the people are extremely adverse (Seinfeld and Pandis, 1997).

Looking at the world organization of public health, they need to incorporate the correlated connection between the respiration diseases, cardiovascular system, allergy disease and air pollution suspended substances, nitrogen dioxide, sulphur dioxide, carbon dioxide phenol, floride hydrogen and lead (Brunekreef and Holgate, 2002; Poschl, 2005).

Pollution in Kazakhstan now threatens the health of thousands of citizens. In 21 of Kazakhstan's cities the air pollution is ten times the accepted safety levels. The World Health Organization states that more 100 thousand people of Kazakhstan die each year from causes directly attributable to air pollution (Cohen et al., 2005; Health Effects Institute, 2004). 
Study region: Rudnyi Altay industrial area is historically well-established and associatively stabilized aggregation, man-made, natural and agricultural complex; characterize the ability to function the environment, to fulfill the definite natural, agricultural and geoecological function.

In organization structure, Rudnyi Altay industrial area consists from natural-resources (natural recourses and conditions, raw materials, affected geosystems, human), industry (architecture and industrial objects, transport, energy, technology and product) and spatial block (geopolitics and economic-geographical regulations conservation strategy, conception, rules, spatial-territory placement).

The Rudnyi Altay industrial region is located in eastern Kazakhstan. The region borders Russia and China. Rudnyi Altay's economy is based primarily on its natural resources, particularly nonferrous metallurgical resources. This region plays an important role in the economy of Kazakhstan. The total population of this region is 671200 , of whom $68 \%$ are urban dwellers and $32 \%$ rural. About $79 \%$ of the population lives in the industrialized cities, which qualify as zones of ecological calamity. The majority of the Rudnyi Altay industrial region of population resides in areas around or near industrial centers, due to the job opportunities offered in these areas. According to national ecological standards, cities such as UstKamenogorsk, Ridder, Zyryanovsk and Shemonaiha have critical environmental indicators (deep ecological changes in all natural systems). The region produces the most lead, zinc, gold, silver, sulphuric acid and also atomic energy raw materials in the country.

The Rudnyi Altay industrial area is well-known just like West-Altai mountains (urbanized industry mining) regions which includes Ust-Kamenogorsk industrial region, Ridder industrial region, Zyryanovsk industrial region, Shemonaiha industrial region, Glubokovskiy industrial region and Irtysh River.

Ust-Kamenogorsk industrial area is an urbanized industry area which includes Ust-Kamenogorsk with suburbs, a powerful complex of the industrial enterprises rendering the extremely negative influence on a condition of an environment: Titan-magnesium combine, Ulba metallurgy factory, chemicalmetallurgical and cement factories, thermal power station, lead-zinc combine. The level of ecological intensity is aggravated with steady ground inversions.

Ridder industrial area is covered by Ridder and the mining enterprises of nonferrous metallurgy. A level of ecological intensity is critical. Factors of ecological destabilization are as follows: Ridder polymetallic combine and its structure of lead-zinc factory, mines, career, dead rock burrow. It is extremely high level of air pollution in the atmosphere. The intermountain hollow defines adverse climatic conditions for dispersion of air pollution.

Zyryanovsk industrial area is included with Zhyryanovsk city, the mining enterprises of nonferrous metallurgy. The greatest negative influence renders lead combine. The level of ecological intensity is critical. The cores pollution natural components: mines and deep career of open-cast mining of ore deposits.

Glubokovskiy industrial area includes the Irtysh polymetallic combine (on reservation), the adjoining mining enterprises and the East Kazakhstan Copperchemical combine. A level of ecological intensity is critical.

Shemonaikha, the urbanized industrial mining enterprises, connects with extraction and processing of copper and zinc ores. Highly disturbed relief and bowels, environmental contamination industrial burrow. The level of ecological intensity is critical.

The Irtysh River is within the limits of Rudnyi Altay industrial area. Strong pollution of the river by industry and household from the cities also effects the Bukhtar, Ulba, Krasnoyask rivers.

The Rudnyi Altay industrial area is characterized by the destabilized geoecological situation and remains a region with unresolved environmental problems.

The non-ferrous sector: The non-ferrous metals sectors makes up for almost $63 \%$ of GDP's Rudnyi Altay. The sector directly contributes $10-15$ percent of total tax revenues. According to Agency of statistics of Kazakhstan, the average annual wage in Rudnyi Altay non-ferrous sector was more than 69.320 tenge in 2008, 24 percent higher than the combined average annual wage for all industries categories. According to Agency of statistics of Republic of Kazakhstan, taxes on production and imports, which includes severance taxes, royalties, fees, property taxes and gross receipts, were about 1.6 million tenge in 2008 .

The Rudnyi Altay home to 4 the main mining operations: Kazzink JSC, Ust-Kamenogorsk TitanMagnesium Plant JSC, Ulba Metallurgical Plant JSC, VostokKazmed Company. This company provided direct employment to more than 36.700 people and another 15.000 people indirectly from mining activity occurring both in and outside the region for a total of more than 50.000 jobs statewide.

Kazzink JSC, Kazakhstan's main zinc producer is controlled by Glencore (Switzerland). The Kazzink Company was formed in 1997 through a merger of three major mining and metallurgical enterprises, the Ust-Kamenogorsk lead and zinc enterprise, the Ridder polymetal enterprise and the Zyryanovsk lead 
enterprise. The Company has five mines, three mills, two zinc plants, sulphuric acid production plant and refining, rare metal production. In 2008, 453.684 of sulphuric acid, 123.769 of lead and 672.603 tonnes of zinc were produced, much of which was exported. The production of this company has been accepted as the standard at the London non-ferrous metals exchange.

Ust-Kamenogorsk Titan-Magnesium Plant JSC is one of the world's 3td largest producers of spongy titanium, magnesium in the form of ingots and powders, vanadium pent-oxide. The enterprise manufactured the spongy titanium of various marks; primary magnesium in ingots, magnesium powder; vanadium pent-oxide in powder. Capacity is rated as over 40.000 tonnes. The high quality of spongy titanium is recognized London non-ferrous metals exchange. UKTM is owned by Specialty Metals Corporation (Belgium).

Ulba Metallurgical Plant JSC is one of the unique manufacture complexes of production of materials for nuclear industry. Since 1997 the enterprise is a part of National atomic company Kazatomprom of the Republic of Kazakhstan. Ulba Metallurgical Plant includes has largest in the CIS countries nuclear fuel manufacture for atomic energetic; manufacture of all kinds of berylliumbearing production from draft ingots to finished products; modern manufacture of fluoric acid.

VostokKazmed Company of Kazahmys Corporation JSC was formed in 1999. It consists of Zhezkent ore mining and processing enterprise, copper-chemical complex, Irtysh copper smeltery, Irtysh and Belousovka mines, Berezovka and Belousovka concentrators. The enterprises belonging to VostokKazmed branch are mining the polymetallic ore at the regional deposits, processing of polymetallic ore with recovery of copper and zinc concentrates, processing of copper concentrates with recovery of draft copper.

Over $90 \%$ of the mineral production is exported since local consumption of metals is relatively low. The productions are exported to former Soviet Union and to international markets.

All auxilliary operations is organized by about 26 stations, plants, mining, complexes, which are located inside region. One of them is Bukhtarma hydroelectric plant. The Bukhtarma hydroelectric plant is located on the Irtysh River $5 \mathrm{~km}$ upstream of the town of Serebryansk. The power station has nine 75MW turbines with a total generating capacity of $675 \mathrm{MW}$. The plant, operated by Ust-Kamenogorsk lead zinc combinate is integrated into Kazakhstan's national electricity system and is used as a peak producer to regulate supply. Bukthtarma generates 2.4 billion $\mathrm{kWh}$ electricity per year which covers $100 \%$ of the metallurgy's electricity needs.
Air quality: Monitoring of the atmospheric condition is conducted on stationary posts in 3 cities in region: Ridder, Ust-Kamenogorsk and Glubokoe.

The main air pollutants are non-ferrous metals and mining industry, their share in total emissions is $69 \%$, enterprise distribution of electricity, gas and water $-22,4 \%$, transport and communications $-6,4 \%$, others $-2,2 \%$.

Of the total amount of pollutants emitted substances (> 160 tons) $81 \%$ were gaseous and liquid substances, 19\%-solid. Of 130 tonnes of gaseous and liquid emissions. $54.8 \%$ was sulfur dioxide, $20.4 \%$-for carbon monoxide, $14.5 \%$-for nitrogen dioxide, $10,3 \%$ for hydrocarbons (excluding volatile organic compounds).

The greatest contributors to air pollution of the Rudnyi Altay industrial area are Ust-Kamenogrsk (47\%), Ridder (17\%) and Glubokoe (16\%).

The list of polluting substances is established in view of volume and structure of emissions in an atmosphere and also results of pilot survey of air pollution in concrete settlement.

The basic criteria of quality are values of maximum admissible concentration (MAC) of polluting substances in the air of the occupied places. The level of pollution on the atmosphere is estimated on size of a complex Index of Air Pollution (IAPs) which pays off on five substances with the greatest rating on maximum concentration limit values in view of their class of danger. Air pollution index is calculated as the sum of the average concentrations of substances for the period divided by maximum admissible concentration reduced to a single indicator: 1

$$
\mathrm{IAP}=\sum_{\mathrm{i}=1}^{\mathrm{n}}\left(\frac{\mathrm{q}_{\mathrm{cp} . \mathrm{i}}}{\mathrm{MPC}_{\mathrm{c} . \mathrm{ci}}}\right)^{\mathrm{C}_{\mathrm{i}}}
$$

Where:

qcp.i = Average for the month, season or year the concentration of $i$-th substance

MAC c.ci $=$ Daily average maximum admissible concentration of i-th substance

$\mathrm{Ci}=$ The exponent, depending on the class of dangerous substance

In all cities of the Rudnyi Altay industrial area, the concentration of MAC is above three and more substances (Table 1).

The maintenance of polluting substances in the atmosphere of the cities of the Rudnyi Altay industrial area remained high in 2008. Average and maximal values of harmful impurity in cities changed in greater 
limits, depending on the size of emissions of the industrial enterprises and also an arrangement of cities in various physical-geographical areas.

The essential part of environmental contamination is connected with dust formation. In atmosphere venomous enrichments, mountain burrows and metallurgical manufactures act from technical waste and breeds from industrial plants. Calculations show that allocation of a dust from decomposition of waste which contains practically all toxic components of mountain-metallurgical manufactures Rudnyi Altay industrial area in a year makes 113 thousand tons. For all the period of mining manufacture in region, dust has exceeded 10 million tones, which means $1 \%$ from all volume of waste. Thus, proceeding from quantity of the extracted ores, the received concentrates and their metallurgical repartition, emissions in the atmosphere only last for 50 years which totals between 8 and 10 million tons (Table 3-5).

Table 1: Dynamics of change in the level of atmospheric pollution of Rudnyi Altay industrial area (IAP5)

\begin{tabular}{llllll}
\hline & IAP5 & & & & \\
& $--1-0$ & & \\
& 2004 & 2005 & 2006 & 2007 & Branch of industry, turning \\
out influence of air pollution
\end{tabular}

Sources: Agency of Statistic of Republic of Kazakhstan.

Table 2: Number of days and percentage in 2008 when the level of pollution of an atmosphere exceeds maximum-admissible is maximal-single concentration

\begin{tabular}{|c|c|c|c|c|c|}
\hline \multirow[b]{2}{*}{ City, settlement } & \multirow[b]{2}{*}{$\begin{array}{l}\text { Name of dirt, } \\
\text { exceeding MAC }\end{array}$} & \multirow[b]{2}{*}{ Number of days } & \multirow[b]{2}{*}{ Percentage $\%$} & \multicolumn{2}{|c|}{ Maximum concentration } \\
\hline & & & & $\mathrm{mg} / \mathrm{m}^{3}$ & Exceeded MAC \\
\hline \multirow[t]{7}{*}{ Ust-Kamenogorsk } & Suspension & 153 & 43,8 & 2,0 & 4,0 \\
\hline & Sulphur dioxide & 8 & 2,3 & 1,530 & 3,1 \\
\hline & Carbon dioxide & 27 & 7,7 & 12 & 2,4 \\
\hline & Nitrogen dioxide & 278 & 79,7 & 0,46 & 5,4 \\
\hline & Phenol & 176 & 50,4 & 0,039 & 3,9 \\
\hline & Floride hydrogen & 26 & 7,4 & 0,051 & 2,6 \\
\hline & On all impurity & 303 & 86,8 & & \\
\hline \multirow[t]{3}{*}{ Ridder } & Nitrogen dioxide & 181 & 59,9 & 0,17 & 2,0 \\
\hline & Phenol & 1 & 0,3 & 0,011 & 1,1 \\
\hline & All of the dirt & 181 & 59,9 & & \\
\hline \multirow[t]{4}{*}{ Glubokoe } & Suspension & 2 & 0,6 & 0,9 & 1,8 \\
\hline & Nitrogen dioxide & 136 & 45,0 & 0,22 & 2,6 \\
\hline & Phenol & 37 & 12,3 & 0,028 & 2,8 \\
\hline & On all impurity & 153 & 50,6 & & \\
\hline
\end{tabular}

Sources: Agency of statistic of republic of Kazakhstan

Table 3: Emissions of air pollutants from stationary sources of pollution, thousand tons

\begin{tabular}{|c|c|c|c|c|c|}
\hline & 2004 & 2005 & 2006 & 2007 & 2008 \\
\hline Ust-Kamenogorsk & 96,3 & 71,1 & 72,8 & 70,6 & 65,2 \\
\hline Ridder & 11,3 & 11,2 & 11,1 & 10,8 & 10,6 \\
\hline Glubokoe & 3,7 & 3,9 & 3,9 & 4,3 & 4,2 \\
\hline Zyryanovsk & 13,4 & 12,2 & 14,6 & 17,4 & 14,5 \\
\hline Shemonaiha & 4,4 & 4,4 & 4,1 & 5,1 & 5,2 \\
\hline Total & 129,1 & 102,8 & 106,5 & 108,2 & 99,7 \\
\hline
\end{tabular}

Sources: Agency of statistic of republic of Kazakhstan

Table 4: Emissions of air pollutants from stationary sources of pollution (solid), thousand tons

\begin{tabular}{|c|c|c|c|c|c|}
\hline & 2004 & 2005 & 2006 & 2007 & 2008 \\
\hline Ust-Kamenogorsk & 7,3 & 6,6 & 7,2 & 5,7 & 4,7 \\
\hline Ridder & 2,0 & 2,1 & 1,9 & 2,0 & 2,3 \\
\hline Glubokoe & 1,7 & 1,9 & 1,5 & 1,7 & 1,7 \\
\hline Zyryanovsk & 6,9 & 6,6 & 7,8 & 8,9 & 6,9 \\
\hline Shemonaiha & 1,8 & 1,9 & 1,7 & 2,5 & 2,6 \\
\hline Total & 19,7 & 19,1 & 20,1 & 20,8 & 18,2 \\
\hline
\end{tabular}

Sources: Agency of statistic of republic of Kazakhstan 
Am. J. Environ. Sci., 7 (3): 286-294, 2011

Table 5: Emissions of air pollutants from stationary sources of pollution (gaseous and liquid), thousand tons

\begin{tabular}{llllll}
\hline & 2004 & 2005 & 2006 & 2007 & \\
\hline Ust-Kamenogorsk & 89,0 & 64,5 & 65,6 & 64,9 & 2008 \\
Ridder & 9,3 & 9,1 & 9,2 & 8,8 & 60,5 \\
Glubokoe & 2,1 & 2,0 & 2,3 & 2,6 & 8,3 \\
Zyryanovsk & 6,5 & 5,6 & 6,8 & 8,5 & 2,4 \\
Shemonaiha & 2,6 & 2,5 & 2,4 & 2,7 & 7,7 \\
Total & 109,5 & 83,7 & 86,3 & 87,5 & \\
\hline
\end{tabular}

Sources: Agency of statistic of republic of Kazakhstan

Table 6: Pollution of air pool of cities of Rudnyi Altay industrial area in 2008

\begin{tabular}{|c|c|c|c|c|c|c|}
\hline \multirow[b]{2}{*}{ City } & \multirow{2}{*}{$\begin{array}{l}\text { Name of dirt } \\
\text { exceeding MAC } \\
\text { exceeding MAC }\end{array}$} & \multicolumn{2}{|c|}{ Average concentration } & \multicolumn{2}{|c|}{ Maximum concentration } & \multirow{2}{*}{$\begin{array}{l}\text { Periodicity of } \\
\text { concentration over } \\
\text { MAC, \% }\end{array}$} \\
\hline & & $\mathrm{Mg} \mathrm{m}^{-3}$ & Exceeded MAC & $\mathrm{mg} / \mathrm{m}^{3}$ & Exceeded MAC & \\
\hline \multirow[t]{9}{*}{ Ust-Kamenogorsk } & Suspension & 0,15 & 1,0 & 2,0 & 4,0 & 6 \\
\hline & Sulphur dioxide & 0,048 & 1,0 & 1,530 & 3,1 & 0,4 \\
\hline & Carbon dioxide & 0,8 & & 12 & 2,4 & 1 \\
\hline & Nitrogen dioxide & 0,06 & 1,5 & 0,46 & 5,4 & 23 \\
\hline & Phenol & 0,003 & 1,0 & 0,039 & 3,9 & 6 \\
\hline & Chloride & 0,004 & & 0,19 & 1,9 & 0,1 \\
\hline & Formaldehyde & 0,006 & 2,0 & 0,056 & 1,6 & 0,1 \\
\hline & Hydrogen floride & 0,002 & & & 2,6 & \\
\hline & & & & 0,051 & & 1 \\
\hline \multirow[t]{4}{*}{ Ridder } & Suspension & 0,15 & 1,0 & 0,30 & & \\
\hline & Sulphur dioxide & 0,092 & 1,8 & 0,243 & & \\
\hline & Nitrogen dioxide & 0,07 & 1,7 & 0,17 & 2,0 & 21 \\
\hline & Phenol & 0,005 & 1,7 & 0,011 & 1,1 & 0,1 \\
\hline \multirow[t]{3}{*}{ Glubokoe } & Suspension & 0,05 & & 0,9 & 1,8 & 0,3 \\
\hline & Nitrogen dioxide & 0,06 & 1,5 & 0,22 & 2,6 & 24 \\
\hline & Phenol & 0,002 & & 0,028 & 2,8 & 4 \\
\hline
\end{tabular}

Sources: Agency of statistic of republic of Kazakhstan

Average concentration of the weighed substances (dust) on cities of Rudnyi Altay industrial area has reached 1.2 MAC. Average concentration of the weighed substances in the cities of Ridder, Ust-Kamenogorsk has reached 1.0-1.8 MAC. In Ust-Kamenogorsk, the maximum from a single concentration of the weighed substances reached 4.0-4.8 MAC, in Glubokoeexceeded 1 MAC.

Average concentration of sulfur dioxide in Ridder and Ust-Kamenogorsk was 1.0-1.8 MAC. In UstKamenogorsk, it is noted that the maximal of single concentration sulphur dioxide equal 3.1 MAC.

Average concentration of sulfates has made 0,006 $\mathrm{mg} \mathrm{m}^{-3}$ (MAC is not present).

Maximal from single concentration carbon dioxide in Ust-Kamenogorsk was more than 1.0-2.4 MAC.

Average concentration of nitrogen dioxide has reached 1.1 MAC. Average concentration of nitrogen dioxide in the cities of Ridder, Ust-Kamenogorsk and Glubokoe was within the limits of 1.0-1.7 MAC. In Ust-Kamenogorsk, it was observed maximal of single concentration nitrogen dioxide equal 5.4 MAC, in the city of Ridder and Glubokoe-within the limits of 2.0-2.9 MAC (Table 6).

Average concentration of phenol has reached 1.2 MAC. Average concentration of phenol in Ridder holds at 1.7 MAC, in Ust-Kamenogorsk -1.0 MAC. In UstKamenogorsk, a maximal of single concentration of phenol equal to 3.9 MAC was observed, in the city of Ridder -1.1-2.0 MAC.

Average concentration of formaldehyde has reached 2.7 MAC. Average concentration of formaldehyde in Ust-Kamenogorsk -2.0 MAC.

In Ust-Kamenogorsk, the average maintenance of fluoric hydrogen was within the limits of norm. In UstKamenogorsk, maximal from single concentration of fluoric hydrogen has made 2.6 MAC.

Maximal from single concentration of chloride hydrogen in Ust-Kamenogorsk reached 1.9 MAC.

In Ridder, Ust-Kamenogorsk and Glubokoe, the average level of air pollution by arsenic was within the limits of admissible standard.

In 2008, comparison with 2007, in the cities of Ridder and Ust-Kamenogorsk, the level of pollution AB considerably did not change, in Glubokoe it decreased.

In 2008, comparison with 2007, in Ridder, UstKamenogorsk and Glubokoe, it is noted that the level of pollution is decreased.

The main air polluters are the enterprises of nonferrous metallurgy and the mining industry, their relative density in total amount of emissions of polluting substances makes $69 \%$, the enterprises of 
distribution of the electric power, gas and water $2,4 \%$, transport and communication $-6,4 \%$, other $-2,2 \%$.

(>160 thousand tons) $81 \%$ have made gaseous and liquid substances of total amount of the thrown out substances of polluting substances, $19 \%$ - firm. In composition of 130 thousand tons of gaseous and liquid emissions of $54,8 \% 20,4 \%$-on carbon oxide, $14,5 \%$ - on nitrogen dioxide, $10,3 \%$-on hydrocarbons (without volatile organic connections) are necessary on sulphur dioxide.

Ust-Kamenogorsk the regional center is characterized by presence of a large number of technical pollution among which it is possible to distinguish the industrial enterprises, transport, gasoline stations, the enterprises of food branch, private inhabited sector. Features of city are the physical-geographical conditions of its arrangement which do not promote the dispersion of polluting substances and also concentration of industrial productions in city boundaries.

Ridder is considered among the most polluted cities of Kazakhstan. In 2007, emissions have made 10.8 thousand tons. The physical-geographical position and a city climate promote that polluting impurity from a lead factory act in city at northeast winds, from the enterprises of a zinc factory, thermal power station at northwest, western directions of a wind. At the developments of stagnation, all polluting impurity remains in city since the city is located in a hollow.

The level of air pollution in settlement Glubokoe remains very high. A high level of organic pollutants and also sulfur dioxide and nitrogen is caused by character of dispersion of harmful impurities from the main industry of Ust-Kamenogorsk in the Irtysh river valley in a direction prevailing with the wind. Vertical and horizontal wind vectors carry pollutants greater distances (some hundreds in $\mathrm{km}$ ).

The ten years of analyzing emissions of polluting substances from stationary sources in an atmosphere of Rudnyi Altay industrial area shows gradual increase in quantity of emissions from 1997 to 2001 and decrease in emissions 2002-2008 and the maximal capacities of the enterprises of nonferrous metallurgy century accordingly quantity of the emissions defining intensity of environmental contamination have been reached in the beginning of $20^{\text {th }}$ century has reached the maximal sizes. With the approach of industrial recession, decrease in investment activity in the middle and the end of $20^{\text {th }}$ century, the volume of emissions has decreased 2.8 times comparing in 1990 Economic growth of industry in 2000 has led to increase in emissions in an atmosphere.
In basic volume structure of polluting substances in the Rudnyi Altay industrial area is $4^{\text {th }}$ place with emissions of 162.7 thousand tons, exceeding Karaganda (1415.4 thousand tons.), Pavlodar (556.8 thousand tons) and Aktyubinsk (168.2 thousand tons).

A significant source of air pollution in the Rudnyi Altay industrial area is motor transport. By virtue of constructive imperfection and lacks of operation, transport emits into the atmosphere more than 200 chemical compounds. Considering motor vehicles as a whole in the region $62 \%$ use gasoline, $36 \%$ - diesel and only $0,2 \%$-the most ecologically safe natural gas.

At the moment, cars use gasoline, lead, chlorine, bromine and diesel engines, causing a significant amount of soot. And practically all types of transport emits into the atmosphere cancerogenic hydrocarbons causing development of cancer.

From 1995-2008 the pollutions have considerably increased emissions from motor transport: on 56 thousand tons a year or $41.7 \%$. The fact shows the increase quantity of vehicles.

In that case, fulfilling gases of cars act in the bottom layer of an atmosphere and process of their dispersion considerably differs from process of dispersion of the high stationary sources, harmful substances are practically in a zone of respiration on the human. Therefore the motor transport should be carried to a category of the most dangerous sources of pollution in the atmosphere.

Health effects: To retrace dynamics of a natural growth of the population for last 10 years from 1996, the death rate exceeds birth rate. And only in 2008, this figure has changed in the positive way. In recent years, vital statistics have continued to deteriorate at a rapid rate due to multiple factors, including the high level of air pollution. For example, birth rates decreased from 18,9 in 2001-13,9 in 2008 (down by $24,1 \%$ ). Mortality rate increased from 9,8 in $2001-12,3$ (up by $24,7 \%$ ). The incidence rates of communicable and noncommunicable diseases have increased. Natural population growth has dropped from $11,8 \%$ in 2001 to $4.6 \%$ in 2008 (or by 3,5 times). Deterioration of various health factors have been mainly caused by both natural and occupational environmental influences (Table 7).

The structure analysis and level of disease for last year's shows direct dependence on a degree of influence of a complex of harmful polluting substances, adverse meteorological conditions and of some other factors rendering combined influence on health of the population. It leads to high level of disease. 
Am. J. Environ. Sci., 7 (3): 286-294, 2011

Table 7: Average population, thousand

\begin{tabular}{|c|c|c|c|c|c|}
\hline & 2004 & 2005 & 2006 & 2007 & 2008 \\
\hline \multicolumn{6}{|c|}{ Average population, thousand people } \\
\hline Ust-Kamenogorsk & 303,6 & 300,8 & 299,1 & 298,5 & 298,5 \\
\hline Ridder & 61,7 & 61,1 & 60,4 & 59,7 & 59,0 \\
\hline Glubokoe & 65,9 & 65,9 & 65,7 & 65,5 & 65,4 \\
\hline Zyryanovsk & 87,2 & 86,2 & 85,3 & 84,5 & 83,6 \\
\hline Shemonaiha & 52,3 & 51,2 & 50,4 & 49,8 & 49,2 \\
\hline Total & 570,7 & 565,2 & 560,9 & 558 & 555,7 \\
\hline \multicolumn{6}{|c|}{$\begin{array}{l}\text { Natural increase (decrease) of } \\
\text { the population, people }\end{array}$} \\
\hline Ust-Kamenogorsk & -693 & -778 & -275 & 251 & 484 \\
\hline Ridder & -637 & -674 & -651 & -722 & -476 \\
\hline Glubokoe & -602 & -578 & -559 & -547 & -398 \\
\hline Zyryanovsk & -685 & -712 & -739 & -664 & -596 \\
\hline Shemonaiha & -387 & -344 & -373 & -329 & -246 \\
\hline
\end{tabular}

Sources: Agency of statistic of republic of Kazakhstan

Table 8: The incidence of tumors per 100 thousand people

\begin{tabular}{llllll}
\hline & 2004 & 2005 & 2006 & 2007 & 2008 \\
\hline Ust-Kamenogorsk & 406,1 & 418,2 & 401,7 & 378,3 & 382,3 \\
Ridder & 384,1 & 388,1 & 369,8 & 414,0 & 385,5 \\
Glubokoe & 388,5 & 395,8 & 352,1 & 338,9 & 393,9 \\
Zyryanovsk & 432,3 & 424,8 & 362,7 & 314,9 & 325,4 \\
Shemonaiha & 414,9 & 359,3 & 373,8 & 334,0 & 360,3 \\
Total & 2025,9 & 1986,2 & 1860,1 & 1780,1 & 1847,4 \\
\hline
\end{tabular}

Sources: Agency of statistic of republic of Kazakhstan

Table 9: Disease of the population East Kazakhstan region on classes of illnesses Registered in the treatment-and-prophylactic organizations

\begin{tabular}{lllll}
\hline Disease & Total & Adult & Teenager & Children \\
\hline All disease & 66835,8 & 49410,8 & 90800,0 & 123396,4 \\
Tumors & 1046,1 & 1383,9 & 99,1 & 104,1 \\
Disease on blood and blood-forming organ & 1467,2 & 704,0 & 2487,5 & 3953,7 \\
Endocrine diseases & 995,5 & 722,3 & 1969,9 & 1690,4 \\
Blood circulation system disease & 1915,9 & 2307,1 & 1330,2 & 661,5 \\
Respiration disease & 27359,8 & 13434,5 & 40351,3 & 74533,9 \\
Digestion disease & 3019,2 & 1904,8 & 4895,7 & 6526,4 \\
Skin disease & 4822,3 & 3899,7 & 6464,8 & 7697,4 \\
Congenital abnor mal, deformation & 91,8 & 25,3 & 176,2 & 310,1 \\
and chromosome damages & & & & 4524,5 \\
Traumas and poisoning & 4963,0 & 4760,9 & & 8657,2 \\
\hline
\end{tabular}

Sources: Agency of statistic of republic of Kazakhstan

In the statistical data of information center-medical of East Kazakhstan, on region, growth of respiration disease, allergic has exceeded a republican parameter on $87 \%$ (Table 8 and 9).

To monitor the process as there is a connection between the phenomena of a correlation analysis of the region: to calculate the correlation coefficients between the level of incidence of malignant tumors and the amount of emissions from stationary sources of Rudnyi Altay industrial area.

Higher morbidity rates have been linked to increasing incidences of conditions such as tumors, respiratory disease, nervous system and sensory organ disturbances, gastrointestinal disease and circulatory disease. Poor air quality has been cited as a factor in these conditions.

Pollution has been found to have a chronically damaging impact on the health of the general population of Kazakhstan (tumors, cancer, respiratory diseases, damage of organs and systems, reduction of total resistance and cardio-vascular diseases).

Health status of the populations is negatively affected by the unfavorable environmental situation, emissions in general and technogenic hotspots.

As seen from the table, there is a significant strong direct correlation between the incidence of malignant tumors and the amount of emissions from stationary sources of Rudnyi Altay industrial area (correlation coefficient $\mathrm{R}=0,6$ ).

In this study was not considered part of emissions of the chemicals, but considered, does aggregate state of substances that make up the emissions at the level of morbidity. Reliably very high positive correlation between the incidence of malignant neoplasms of the population and the number of emissions of substances in gaseous and liquid state $(\mathrm{R}=0,6)$ and a weak correlation with the solids $(\mathrm{R}=-0,2)$. 
Am. J. Environ. Sci., 7 (3): 286-294, 2011

Table 10: Pearson's correlation coefficient, $\mathrm{R}$ between the level of malignant tumors and the amount of emissions from stationary sources of Rudnyi Altay industrial area

\begin{tabular}{|c|c|c|c|}
\hline & \multicolumn{3}{|c|}{ Pearson's correlation coefficient, $\mathrm{R}$} \\
\hline & Total & Solid & Gaseous and liquid \\
\hline 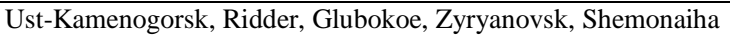 & 0,6 & $-0,2$ & 0,6 \\
\hline
\end{tabular}

Table 11: Regressive model of the dependence of malignant tumors and the amount of emissions from stationary sources of Rudnyi Altay industrial area

\begin{tabular}{lll}
\hline & Regressive model & Solid \\
\hline $\begin{array}{l}\text { Ust-Kamenogorsk, Ridder, Glubokoe, } \\
\text { Zyryanovsk, Shemonaiha }\end{array}$ & $\mathrm{y}=5,625 \mathrm{x}+1519 \mathrm{R}^{2}=0,671 \quad \mathrm{y}=5,458 \mathrm{x}+1543 \mathrm{R}^{2}=0,651$ \\
& $\begin{array}{l}\mathrm{y} \text { - the value of malignant tumors per 100000 population; } \mathrm{x} \text { - emissions from stationary sources, } \\
\text { thousands ton per year. }\end{array}$ \\
\hline
\end{tabular}

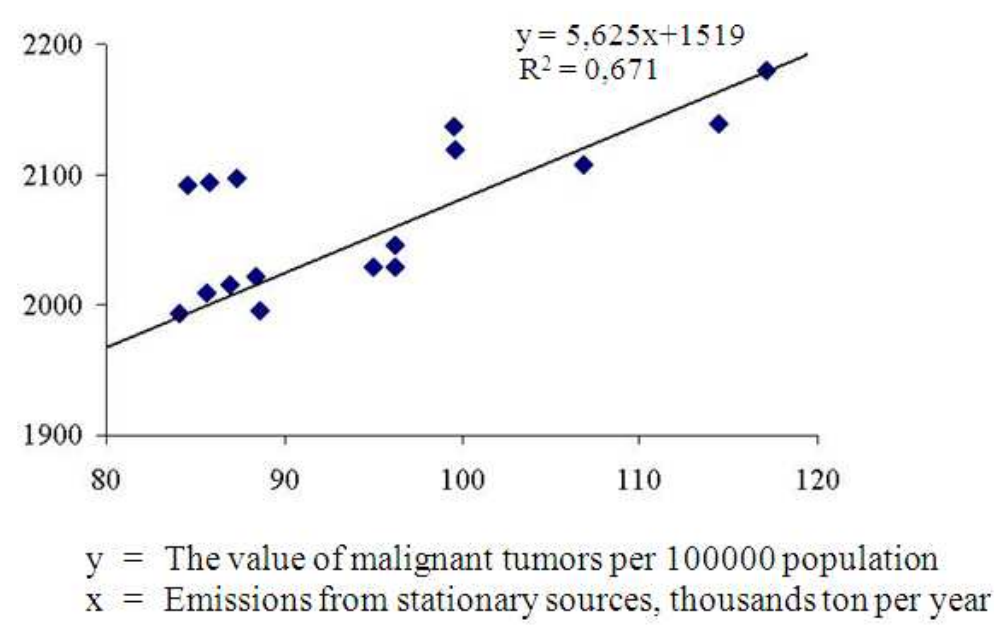

Fig. 1: Empirical regression line for the dependence of malignant neologism and the amount of emissions from stationary sources of Rudnyi Altay industrial area

Slow connection with the incidence of solids due to the low percentage of emissions. The bulk of the emissions accounted for gaseous and liquid substances. The coefficients of correlation made it possible to assess the direction and strength of the relationship between rates of morbidity and the level of risk to health (Table 10).

The model indicates the incidence of malignant tumors and the amount of emissions from stationary sources of Rudnyi Altay industrial area $\mathrm{y}=5,625 \mathrm{x}$ $+1519, \mathrm{R}^{2}=0,671$, $\mathrm{y}$-the value of malignant tumors per 100000 population; $\mathrm{x}$-emissions from stationary sources, thousands ton per year.

The model indicates the incidence of malignant tumors and the amount of emissions (gaseous and liquid) from stationary sources of Rudnyi Altay industrial area $y$ $=5,458 \mathrm{x}+1543, \mathrm{R}^{2}=0,651 \mathrm{y}$-the value of malignant tumors per 100000 population; X-emissions from stationary sources, thousands ton per year.
The model relates the incidence of malignant tumors and the amount of emissions (solid) from stationary sources of Rudnyi Altay industrial area $\mathrm{y}=$ $2554,8-26,6 \mathrm{x}, \mathrm{R}^{2}=0,3$, $\mathrm{y}$-the value of malignant tumors per 100000 population; x-emissions from stationary sources, thousands ton per year (Fig. 1 and Table 11).

Selection on the influence of suspension particles in the air surface on the people's population condition. Dusty atmosphere allow bad ultraviolet radiation, possessing bacterial properties and inhibiting auto purification atmosphere. Dust clogs mucous membrane respiration system and eyes, irritates covering of person and appears to carrier of bacteria and virus. Carbonblack, component dust and present itself nearly pure carbon atmosphere, increasing readily morbidity (Localization malignant cancer of morbidity respiration in Rudnyi Altay industrial area occupies first place) (Bradl, 2005; Yang and Stanley, 2009). 
The Rudnyi Altay industrial area occupies second place in the republic on the morbidity malignant tumors after the Karaganda region in respiration diseases after Almaty. This fact is shown in unfavorable ecological situation in the region; especially as concerning death from malignant tumors, the region ranks first in the country.

\section{CONCLUSION}

- The dangerously high level of air pollution in Rudnyi Altay, due to multiple sources including various industrial enterprises and automobile emissions, is threatening the health and well being of Kazakhstani citizens

- The main sources of air pollution are non-ferrous metallurgy

- Established stable air pollution in the region includes a broad spectrum of chemical compounds, such as: Balanced, nitrogen dioxide, sulfur dioxide, the levels of these pollutants in the atmosphere exceed maximum admissible standards by a factor of 1,5-2 times

- It was demonstrated that a causal relationship between the amounts of emissions from malignant diseases exists

- The influence of air pollution on the status of population's health really depends on ecological situations, same as to other factors, conditional territory spatial organization individual potential architectural, meteorological and others especially of territory areas. As a result, in a concern of improving ecological scenery and the quality of the population people's condition must be solved while calculating the effect of specific factors

- Government officials and public health representatives are prioritizing preventative tasks and proactive plans such as the National Environmental Health Action Plan to combat the issue of air pollution and problems associated with it

\section{REFERENCES}

Bradl, H.B., 2005. Heavy Metals in the Environment. 1st Edn., Elsevier Academic Press, Amsterdam, ISBN: 0120883813, pp: 269.

Brunekreef, B. and S.T. Holgate, 2002. Air pollution and health. Lancet, 360: 1233-1242. DOI: 10.1016/S0140-6736(02)11274-8
Ezzati, M., A.D. Lopez, C.J.L. Murray and A. Rodgers 2005. Comparative Quantification of Health Risks: Global and Regional Burden of Diseases Attributable to Selected Major Risks. 1st Edn., World Health Organization, Geneva, ISBN-10: 9241580313, pp: 2278

Dahl, C. and K. Kuralbayeva, 2001. Energy and the environment in Kazakhstan. Energy Policy, 29: 429-440. DOI: 10.1016/S0301-4215(00)00137-3

Farmer, A. and A.M. Farmer, 2000. Concentrations of cadmium, lead and zinc in livestock feed and organs around a metal production centre in Eastern Kazakhstan. Sci. Total Environ., 257: 53-60. DOI: 10.1016/S0048-9697(00)00497-6

Health Effects Institute, 2004. Health effects of outdoor air pollution in developing countries of Asia: A Literature Review. $1^{\text {st }}$ Edn., Health Effects Institute, Boston, pp: 117.

Jensena, S., Z. Mazhitova and R. Zetterström, 1997. Environmental pollution and child health in the Aral Sea region in Kazakhstan. Sci. Total Environ., 206: 187-193. DOI: 10.1016/S00489697(97)80009-5

Kaiser, M. and A.G. Pulsipher, 2007. A review of the oil and gas sector in Kazakhstan. Energy Policy, 35: 1300-1314. DOI: 10.1016/J.ENPOL.2006.03.020

Namazbaeva, Z.I., N.K. Diusembaeva, M.A. Mukasheva and K.I. Sadykov, 2010. Risk Factors for Reproductive Dysfunction Under the Influence of a Territorial Industrial Complex. Gig. Sanit. PMID: 20376937

Poschl, U., 2005. Atmospheric aerosols: Composition, transformation, climate and health effects. Angew. Chem. Int. Edn., 44: 7520-7540. DOI: 10.1002/ANIE.200501122 PMID:16302183

Seinfeld, J.H. and S.N. Pandis, 1998. Atmospheric Chemistry and Physics. 1st Eden., Wiley, New York, ISBN: 0471178160, pp: 1326.

Yang, W. and S.T.Omaye, 2009. Air pollutants, oxidative stress and human health. Mutation Res./Genetic Toxicol. Environ. Mutagenesis, 674: 45-54. DOI: 10.1016/J.MRGENTOX.2008.10.005 PMID: 19013537 